\title{
Ethno-Environmental Knowledge as A Tool to Combat Indoor Air Pollution in Low Income Countries: A Case Study from Rural Communities in Pakistan
}

\author{
Zaheer Ahmad Nasir ${ }^{1,2}$, Ian Colbeck ${ }^{1 *}$, Zareen P Bharucha ${ }^{1}$, Luiza Cintra \\ Campos $^{2}$ and Zulfiqar Ali ${ }^{3}$ \\ ${ }^{1}$ School Biological Sciences, University of Essex, CO4 3SQ, UK. \\ ${ }^{2}$ Healthy Infrastructure Research Centre, Department of Civil, Environmental \& Geomatic Engineering, University College \\ London, London WC1E 6BT, UK. \\ ${ }^{3}$ Department of Zoology, University of the Punjab, Lahore, Pakistan \\ *Corresponding author: colbi@essex.ac.uk
}

\begin{abstract}
:
It has recently been estimated that 4 million deaths each year are associated with air pollution originating from household solid fuel use. Interventions to reduce biomass fuel-related emissions can yield a diverse stream of benefits including improved public health, socio-economic development, reduced land degradation and climate change mitigation. This study investigates the use of indigenous knowledge to inform interventions to combat indoor air pollution at a rural site in the Punjab province of Pakistan. The results indicate that the majority of people using biomass fuel had knowledge of its ill health effects. A range of methods were utilised to reduce indoor smoke including cooking in open spaces, use of chimneys, better ventilation and use of dry fuel. Education and housing type showed a statistically significant relationship with awareness of methods to reduce indoor exposure to biomass smoke. These findings lend support to the notion that communities have indigenous knowledge and their own methods to reduce exposure to indoor smoke from biomass fuels; this knowledge can be used as tool to design and implement sustainable intervention strategies to reduce the risk of exposure to indoor air pollution. It is recommended that a community based intervention focusing on locally manufactured improved stoves and better designed cooking spaces would be a suitable intervention in this region.
\end{abstract}

Keywords:

Indoor Air Pollution; Indigenous Knowledge; Interventions

\section{INTRODUCTION}

Indoor air pollution from biomass fuel use, as a source of household energy, poses serious threats to human health and contributes to environmental degradation. Worldwide, over 3 billion people, largely in developing countries, rely on biomass fuels (wood, dung and crop residues) for their household 
energy needs [1]. Of these, only a small proportion (some 830 million) employ measures which reduce their exposure to indoor air pollution, such as improved cooking stoves [2]. Solid biomass fuels have traditionally been burnt in a variety of stoves with poor combustion efficiency under conditions of limited ventilation. The resulting smoke contains a range of substances that can pose a serious threat to human health, especially for women and young children [3]. This smoke has been linked with acute infection of the lower respiratory tract, chronic obstructive pulmonary disease (COPD), and lung cancer (especially from coal use) [4]. It has recently been estimated that the air pollution produced from cooking with solid fuels kills 4 million people annually and within South Asia is the third highest risk factor for causes of death [5]. Apart from public health impacts biomass fuel emissions are also implicated in other environmental concerns such as global warming [6].

Pakistan is the world's sixth most populous country with an estimated population of 184.35 million in 2013 and almost $62 \%$ of the population lives in rural areas [7]. The use of biomass fuels is widespread; $62 \%$ of the population uses it as a source of energy for the household. $86 \%$ of rural and $16 \%$ of urban households use biomass fuels for cooking [8]. According to the Pakistan Strategic Country Environmental Assessment by the World Bank [9], indoor air pollution accounts for 28,000 deaths per year and 40 million cases of acute respiratory illness. Despite the mounting evidence that indoor pollution poses a significant health impact, the problem has received relatively little attention from government and academics and studies on levels of indoor air pollution in Pakistani households are scant [10-14].

Interventions to reduce biomass fuel-related emissions can yield a diverse stream of benefits including improved public health and socioeconomic development, reduced land degradation and climate change mitigation. Household energy use is linked to many of the Millennium Development Goals. In particular, eradicating extreme poverty and hunger (Goal 1), achieving universal primary education (Goal 2), promoting gender equality and empowering women (Goal 3), reducing child mortality (Goal 4), improving maternal health (Goal 5) and ensuring environmental sustainability (Goal 7). The WHO suggests that the "proportion of the population using solid fuels for cooking" is an indicator for assessing progress towards Goal 7 and integration of principles of sustainable development in countries polices [15].

Interventions can be grouped into three types based on their focus: (1) those which address the source of pollution, (2) those which address the indoor environment of the cooking space and (3) those which attempt to influence user behavior. Interventions focused on the source of pollution involve switching to cleaner fuels. However, choice of household energy fuel is strongly linked to many socioeconomic factors and has strong links with poverty. Subsidizing cleaner fuel is often not feasible and can be seriously constrained due to lack of availability and cost of cleaner fuels. The development and subsidization of improved cook stoves has become another widely used intervention. They have been recommended as a cost-effective way to reduce the burden of disease associated with exposure to indoor air pollution [16]. The design of the kitchen, the location of the stove and increased ventilation all target the environment of the cooking space $[17,18]$. Overall the success of the various cookstove programs has been reported as mixed [19].

Since the early 1980s, improved stove programmes have commenced in many developing countries. The largest and longest are the Indian National Programme for Improved Chulhas (NPIC) and the Chinese National Improved Stove Program (NISP). Between 1980 and 1990 the Government of India subsidized and distributed 32 million improved stoves [20]. However, it was observed that NICP made no significant contribution to improvements in fuel efficiency and indoor air quality [21, 22]. By contrast, NISP is a success story and reductions in both fuel use and air pollution have been documented [23]. This success lay in the extensive participation of women and the distribution of stove designs suitable to the community, supported by technical and administrative support by the government with a limited subsidy [22,23]. In 
the case of India a heavy subsidy from the government and a lack of local community participation and knowledge of their needs were identified as the causes of failure. The development and dissemination efforts/programmes of improved biomass stoves and biogas plants in Pakistan have been discussed in detail by [10, 24-28].

Many communities using biomass fuels are aware of their effects as irritants to the eyes or as the cause of headaches. It is very likely that communities are aware of indoor air pollution and have traditional methods to reduce it. Use of these methods may, however, be limited for a variety of reasons - just as use of 'improved' stoves is limited.

It can thus be argued that:

1. any intervention must not overlook the complex interactions of household energy use and many socio-economic factors in a specific community;

2. traditional knowledge is likely to be important in combating indoor air pollution;

3. indigenous knowledge of methods to reduce indoor air pollution can contribute to the success of community based interventions. These interventions would be more viable and widely accepted in the local communities as they recognize the existing limits in economic resources, social norms, and human behaviour.

We hypothesize that local communities have traditional knowledge of methods to reduce indoor air pollution. However, documentation of such knowledge has been largely ignored. This study describes such local knowledge within a community in Pakistan and analyses the barriers and bridges to the implementation of such knowledge. In doing so it provides a solid base upon which to deploy further community-based programmes to reduce indoor air pollution.

\section{METHODS}

\subsection{Site and study Population}

The rural site selected for the present investigation was located in District Okara of Punjab province. Okara is located southwest of Lahore (Capital of Punjab) and the sampling village was $15 \mathrm{~km}$ away from Okara. The village has approximately 450 households and a population of 2,500. The houses were made of brick walls, either plastered with cement or mud, with roofs of a combination of wood and bricks or wood with straw. The main livelihood was irrigated agriculture. Owing to differences in ownership of the agricultural land, there was mix of lower and middle socioeconomic class families. The main household fuel was biomass, mainly wood, dung and crop residue. Liquefied petroleum gas (LPG) cylinders were available in the nearby city.

\subsection{Sampling and Questionnaire}

Respondents were selected opportunistically covering 125 households. A structured questionnaire was designed particularly for the purpose of this study. Questions focused on household characteristics, 
Table 1. Household characteristics of study population

\begin{tabular}{|c|c|c|c|c|c|}
\hline & Mean & Minimum & Maximum & Standard Deviation & \\
\hline Age (Years) & 43 & 18 & 90 & 17.38 & \\
\hline \multirow[t]{2}{*}{ Number of Children } & 3.7 & 0 & 10 & 2.96 & \\
\hline & Male & Female & & & \\
\hline \multirow[t]{2}{*}{ Gender } & $80 \%$ & $20 \%$ & & & \\
\hline & Tiled roof & Untiled roof & & & \\
\hline \multirow[t]{2}{*}{ Housing type } & $40 \%$ & $60 \%$ & & & \\
\hline & Combined & Separate & & & \\
\hline \multirow[t]{2}{*}{ Family System } & $60 \%$ & $40 \%$ & & & \\
\hline & Yes & No & & & \\
\hline \multirow[t]{2}{*}{ Source of earning } & $87 \%$ & $13 \%$ & & & \\
\hline & Yes & No & & & \\
\hline \multirow[t]{2}{*}{ Husband helps with cooking } & $63 \%$ & $37 \%$ & & & \\
\hline & None & Primary & Middle & Secondary & Graduate \\
\hline Education & $53 \%$ & $16.7 \%$ & $20 \%$ & $6.7 \%$ & $3.3 \%$ \\
\hline
\end{tabular}

type of fuel usage and respondents' reasons for their fuel choice, awareness of the association between different cooking fuels and general health, awareness and uses of various methods to reduce cooking smoke, willingness to change cooking practices and hindrance to change cooking practices. Questions regarding the awareness and use of various methods to reduce cooking smoke exposure were adopted from WHO [29]. Statistical analysis was carried out with SPSS (version 16) in order to identify relationships between different household characteristics and fuel choice, awareness of the health impacts of indoor air pollution and traditional knowledge of methods used to reduce indoor smoke.

\section{RESULTS AND DISCUSSION}

\subsection{Household Characteristics}

Table 1 lists the household characteristics of the respondents. It is evident that there were far more male respondents than female. This is because males are more often the head of their households in the study area and have a relatively greater say in household decisions. Cultural norms also made the participation of female respondents relatively difficult.

\subsection{Features of household fuel use}

As expected, biomass fuel was the predominant household energy source and a wide range of stoves were used (Table 2). Eighty seven percent of the households used only biomass fuel (wood, dung and crop residue) while $13 \%$ used both biomass fuel and Liquefied Petroleum Gas (LPG). In deciding the fuel type, the wives had a major share ( $83 \%$ ) followed by both husband and wife (10\%) and husband only (7\%). The extensive use of biomass fuel was due to the low cost and availability. The higher percentage of wives in the decision making processes is probably the result of their contribution to the collection of biomass fuel. Women were generally involved in the production of dung cake and collection of crop 
Table 2. Salient features of household fuel use

\begin{tabular}{|c|c|c|c|c|c|}
\hline & Biomass & Both & & & \\
\hline \multirow[t]{2}{*}{ Fuel group } & $87 \%$ & $13 \%$ & & & \\
\hline & Husband & Wife & Both & & \\
\hline Fuel type decision & $7 \%$ & $83 \%$ & $10 \%$ & & \\
\hline Fuel choice rank & 1 & 2 & 3 & 4 & None \\
\hline Cost & $90 \%$ & $7 \%$ & - & - & $3 \%$ \\
\hline Availability & $7 \%$ & $70 \%$ & $3 \%$ & - & $20 \%$ \\
\hline Environmental Friendliness & - & - & - & - & $100 \%$ \\
\hline Comfort & - & - & $3 \%$ & - & $97 \%$ \\
\hline Health Issues & - & - & - & - & $100 \%$ \\
\hline \multirow[t]{2}{*}{ Cooking time } & - & - & $23 \%$ & $3 \%$ & $74 \%$ \\
\hline & Yes & No & Don't Know & & \\
\hline Biomass fuel advantages & $60 \%$ & $20 \%$ & $20 \%$ & & \\
\hline Cheap & $67 \%$ & $33 \%$ & & & \\
\hline \multirow[t]{2}{*}{ Easily available } & $44 \%$ & $56 \%$ & & & \\
\hline & Living area & Indoor Kitchen & Outdoor Kitchen & $\begin{array}{l}\text { Winter indoors and } \\
\text { summer outdoors }\end{array}$ & \\
\hline \multirow[t]{2}{*}{ Cooking place } & $0 \%$ & $3 \%$ & $33 \%$ & $64 \%$ & \\
\hline & $<1$ hour & $2-3 \mathrm{hrs}$ & 4-5 hrs & $-7 \mathrm{hrs}$ & $>7 \mathrm{hrs}$ \\
\hline Time spent on cooking & $3 \%$ & $44 \%$ & $50 \%$ & $3 \%$ & \\
\hline
\end{tabular}

residue. Respondents ranked fuel cost and availability as being the most important factors determining the decision on fuel type, followed by cooking time and comfort. Environmental friendliness and health issues did not receive any consideration. The importance of cost and availability was further highlighted when $60 \%$ of the participants identified these advantages.

A vast majority of households carry out indoor cooking during the winter and outdoors in the summer (64\%). There were huge differences in kitchen designs and most of these were built by local inhabitants, according to their demands. The outdoor kitchens could be roofed or unroofed.

\subsection{Awareness of health impacts of cooking fuels}

Most of the people were aware that cooking fuels have health impacts and a large proportion (77\%) had knowledge that some fuels were better for health than others. Natural gas and LPG were perceived to be the best fuels. In addition the majority of respondents were aware and agreed that cooking with biomass fuel had a negative effect on their children's health (Table 3). The studies by Edelstein et al. [30] and Osagbemi et al. [31] had also shown considerable awareness of ill health effects of biomass fuel use in their studied communities. It is of note that a considerable proportion placed wood as the best fuel along with natural gas and LPG. The likely reason is the better cooking efficiency of wood in comparison to dung and crop residue. 
Table 3. Awareness of health impacts of cooking fuel.

\begin{tabular}{|c|c|c|c|c|c|}
\hline & Yes & NO & Do not Know & & \\
\hline \multirow[t]{2}{*}{$\begin{array}{l}\text { Are some cooking fuels better } \\
\text { for one's health? }\end{array}$} & $77 \%$ & $6 \%$ & $17 \%$ & & \\
\hline & Biomass $^{1}$ & Clean $^{2}$ & Both & & \\
\hline \multirow[t]{2}{*}{ Which fuel is the best for one's health? } & $13 \%$ & $40 \%$ & $27 \%$ & & \\
\hline & Stronglyagree & Agree & Neutral & Disagree & Strongly disagree \\
\hline $\begin{array}{l}\text { Does biomass fuel affect you or } \\
\text { your children's health? }\end{array}$ & $40 \%$ & $33 \%$ & $10 \%$ & $3 . \%$ & $14 \%$ \\
\hline
\end{tabular}

Table 4. Awareness of various methods to reduce exposure to biomass fuel smoke

\begin{tabular}{lll}
\hline $\begin{array}{l}\text { Ywareness of any method to reduce } \\
\text { smoke during cooking }\end{array}$ & $87 \%$ & No \\
\hline $\begin{array}{l}\text { Changing the source of pollution } \\
\text { (Yes, No, N/A) }(\%)\end{array}$ & $\begin{array}{l}\text { Improving the cooking environment } \\
\text { (Yes, No, N/A) }(\%)\end{array}$ & $\begin{array}{l}\text { Modifying user behaviour } \\
\text { (Yes, No, N/A) (\%) }\end{array}$ \\
\hline $\begin{array}{l}\text { Improved stoves } \\
(0,90,10)\end{array}$ & $\begin{array}{l}\text { Stoves with chimneys } \\
(57,33,10)\end{array}$ & $\begin{array}{l}\text { Fuel drying } \\
(87,3,10)\end{array}$ \\
\hline $\begin{array}{l}\text { Alternative /combination of fuels } \\
(10,80,10)\end{array}$ & $\begin{array}{l}\text { Improved ventilation } \\
(83,7,10)\end{array}$ & $\begin{array}{l}\text { Good maintenance of stoves and } \\
\text { chimneys and other appliances } \\
(0,90,10)\end{array}$ \\
\hline $\begin{array}{l}\text { Liquefied petroleum gas } \\
(10,80,10)\end{array}$ & $\begin{array}{l}\text { Kitchen separate from house reduces exposure Reductions by avoiding smoke; } \\
\text { of family } \\
(0,90,10)\end{array}$ & $\begin{array}{l}\text { Keeping children away } \\
\text { smoke } \\
(3,87,10)\end{array}$ \\
\hline $\begin{array}{l}\text { Natural gas } \\
(30,60,10)\end{array}$ & $\begin{array}{l}\text { Kitchen design and placement } \\
\text { of the stove } \\
(10,80,10)\end{array}$ & $\begin{array}{l}\text { Stove at waist height reduces direct exposure } \\
\text { of cook leaning over fire } \\
(0,90,10)\end{array}$ \\
\hline $\begin{array}{l}\text { Biogas } \\
0,90,10\end{array}$ & & \\
\hline
\end{tabular}

\subsection{Awareness and use of methods to reduce exposure to biomass fuel smoke}

A vast majority (87\%) was aware of some methods to reduce indoor air pollution exposure. Their awareness was matched against the intervention methods mentioned previously - i.e., changing the source of pollution, improvement in the cooking environment and modifying the user behaviour (Table 4).

With regard to the first (changing the source of the pollution), respondents mentioned the use of natural gas (30\%), LPG (10\%) and a combination (10\%) of fuels. When considering the cooking environment, respondents were aware of strategies such as improving ventilation (83\%), use of a chimney (57\%) and better kitchen design (10\%). In modifying the user behaviour by changing the cooking practice, use of dry fuel (87\%) was proposed by all the participants who declared awareness (Table 4).

With reference to the method used in changing the pollution source, a combination of LPG with biomass fuels (13\%) was used. Improved ventilation (83\%) and chimneys (20\%), along with kitchen design and placement of stove (10\%) were used to improve the cooking environment while in modifying the user behaviour, the use of dry fuel ( $87 \%$ ) was mentioned (Table 5). It can be seen that there were more 
Table 5. Use of various methods to reduce exposure to biomass fuel smoke.

\begin{tabular}{|c|c|c|}
\hline $\begin{array}{l}\text { Changing the source of pollution } \\
\text { (Yes, No, N/A) }(\%)\end{array}$ & $\begin{array}{l}\text { Improving the cooking environment } \\
\text { (Yes, No, N/A) }(\%)\end{array}$ & $\begin{array}{l}\text { Modifying user behaviour } \\
(\text { Yes, No, N/A)(\%) }\end{array}$ \\
\hline $\begin{array}{l}\text { Improved Stoves } \\
(0,90,10)\end{array}$ & $\begin{array}{l}\text { Stoves with chimneys } \\
(20,77,3)\end{array}$ & $\begin{array}{l}\text { Fuel drying } \\
(87,10,3)\end{array}$ \\
\hline $\begin{array}{l}\text { Alternative /combination of fuels } \\
(13,83,4)\end{array}$ & $\begin{array}{l}\text { Improved ventilation } \\
(83,13,4)\end{array}$ & $\begin{array}{l}\text { Good maintenance of stoves and } \\
\text { chimneys and other appliances } \\
(0,97,3)\end{array}$ \\
\hline $\begin{array}{l}\text { Liquefied petroleum gas } \\
(0,97,3)\end{array}$ & $\begin{array}{l}\text { Kitchen separate from house reduces exposure } \\
\text { of family } \\
(0,97,3)\end{array}$ & $\begin{array}{l}\text { Reductions by avoiding smoke; } \\
\text { Keeping children away from } \\
\text { smoke } \\
(0,97,3)\end{array}$ \\
\hline $\begin{array}{l}\text { Natural gas } \\
(0,97,3)\end{array}$ & $\begin{array}{l}\text { Kitchen design and placement of the stove } \\
(10,87,3)\end{array}$ & \\
\hline $\begin{array}{l}\text { Biogas } \\
(0,97,3)\end{array}$ & $\begin{array}{l}\text { Stove at waist height reduces direct exposure } \\
\text { of cook leaning over fire } \\
(0,97,3)\end{array}$ & \\
\hline
\end{tabular}

Table 6. Willingness to change fuel or adopt an improved stove.

\begin{tabular}{|c|c|c|c|c|c|}
\hline & Yes & No & Do not know & & \\
\hline Availability of clean fuel? (LPG) & $93 \%$ & $3 \%$ & $4 \%$ & & \\
\hline Willingness to change fuel? & $93 \%$ & $3 \%$ & $4 \%$ & & \\
\hline \multicolumn{6}{|l|}{ Hindrance to use clean fuel? } \\
\hline Cost & $97 \%$ & $3 \%$ & & & \\
\hline \multirow[t]{2}{*}{ Family members } & $11 \%$ & $89 \%$ & & & \\
\hline & Very likely & Likely & Neutral & Unlikely & Very unlikely \\
\hline Buying an improved stove & $67 \%$ & $17 \%$ & $10 \%$ & $3 \%$ & $3 \%$ \\
\hline Replacing old stove with free improved stove & $87 \%$ & $7 \%$ & $3 \%$ & & $3 \%$ \\
\hline Adopting an improved stove made within own village & $70 \%$ & $24 \%$ & $3 \%$ & & $3 \%$ \\
\hline
\end{tabular}

respondents who use some methods to reduce biomass smoke exposure than who mentioned awareness of any method. It is reasonable to conjecture that almost all the people using biomass fuel employ some methods to reduce the smoke exposure, though they may not be aware of the health impacts. In addition, $60 \%$ of the respondents agreed that the amount of smoke varies with stove type. A similar figure agreed that kitchen design had a significant impact on exposure to biomass smoke.

\subsection{Willingness to change the fuel and cooking practices and hindrance}

The vast majority (93.3\%) were aware of the availability of clean fuel (LPG) and they expressed willingness to switch to it. However, $87 \%$ were still using biomass fuel and only a small percentage (13\%) was using a combination of biomass and LPG. The cost of the cleaner fuel was highlighted as the biggest obstacle (97\%) to its use. Moreover, a minor fraction (11\%) identified family members as being a hindrance to its adoption. With reference to improved stoves, $84 \%$ showed their interest to buy an improved stove. The choice to have a free improved stove raised this figure up to $94 \%$. The same percentage was willing to adopt an improved stove produced by the village. In addition $90 \%$ of the people believed that older villagers have better knowledge than younger ones as how to reduce smoke exposure. 
It is clear that almost all the biomass fuel users were willing to switch to cleaner fuel but the cost involved was the limiting factor. Cheap and the free availability of biomass fuel (crop residues and dung) played a pivotal role in fuel choice.

The choice of household fuel is linked to many social and economic factors. The energy ladder model of fuel use predicts that households will switch from traditional fuels to cleaner ones with an increase in income. However, the situation is often complex and varies across different communities and localized environments [32, 33]. According to Balakrishnan et al. [34] in rural areas the use of multiple types of stoves and fuels simultaneously is wide spread and a shift in fuel type is generally not complete or unidirectional. There are many other factors which could hinder or delay the process of this transition. For example, cheap availability of biomass fuel, unawareness of the link between fuel choices, cooking technology, and health cost due to indoor air pollution, unavailability or high setup cost of cleaner fuels and cultural factors may make cleaner fuels less attractive.

\subsection{Relationship between various variables and awareness and use of methods to re- duce indoor smoke}

In order to identify the relationship between household characteristics, their awareness and methods used to reduce indoor smoke cross tabulation was carried out. A statistically significant relationship was found between education and awareness of methods to combat indoor air pollution. This relationship was for use of a chimney $\left(\chi^{2}=14.13 ; \mathrm{p}<0.10\right)$ and keeping children away from smoke $\left(\chi^{2}=31.55 ; \mathrm{p}<0.05\right)$. The housing type was also significantly related $\left(\chi^{2}=6.563 ; \mathrm{p}<0.05\right)$ to awareness of kitchen design and placement of stove. As regards intervention methods, fuel drying showed a significant relationship $\left(\chi^{2}=6.923 ; \mathrm{p}<0.05\right)$ with housing type. No statistically significant relationship was found for family system and earning and awareness and use of different intervention methods. Education was significantly related to fuel group $\left(\chi^{2}=10.34 ; \mathrm{p}<0.05\right)$ and awareness that different stoves produce different amounts of smoke $\left(\chi^{2}=34.40 ; p<0.05\right)$. However education did not show any statistically significant relationship with knowledge of ill health effects although people who denied any association of biomass fuel use and ill health had either no education or only primary education. Similarly no relationship was found between earning and fuel group.

\section{CONCLUSION AND RECOMMENDATIONS}

Almost 3 billion people in the world rely on biomass fuel for cooking, heating and lighting. This has resulted in a significant health burden from indoor air pollution due to smoke. A large number of interventions are in place and some have shown a reduction in the health effects. The use of improved cooking devices has been widely used as an intervention in low income and developing countries. However, little attention has been paid to community knowledge as an intervention to combat indoor air pollution. The present study shows that the majority of people using biomass fuel had knowledge of its ill health effects. In addition they were, not only, aware of ways to reduce it but were also using some methods to overcome indoor smoke. Their awareness included cooking in open spaces, use of chimneys, better ventilation and use of dry fuel. They also had knowledge of the impact of stove type on smoke production and kitchen design to reduce indoor smoke exposure. Education and housing type showed an impact on the awareness towards methods to reduce indoor exposure to biomass smoke. It is of note that the 
study population did not have any planned intervention. Moreover they were willing to change their fuel or use improved stoves and indicated a likelihood to adopt an improved stove designed by their own community. Based on the results of this study it can be seen that a community based intervention focusing on improved stoves and a better designed cooking spaces would a suitable intervention.

This study provides evidence that communities posses knowledge and their own ways to reduce indoor smoke. For a cost effective and sustainable intervention their knowledge must be utilised and it is very likely that any intervention without valuing their knowledge and taking into account socio-economic conditions would prove futile. The following parameters need to be considered before designing an intervention programme:

1. The knowledge of the local community to reduce indoor air pollution must be documented with a view to inform potential intervention strategies.

2. Intervention tools/strategies should be tailored according to the needs of the local community, climatic conditions, ecosystem services, and socio-economic conditions.

3. Design, development and dissemination of intervention tools/strategies should use local resources and people. This could result in an income opportunity for local people especially women.

4. Suitable incentives could be used to attract people to use various interventions, but subsidies should be limited.

5. Awareness of the health and financial benefits of a reduction in indoor air pollution should be a component of any intervention programme.

6. An integrated effort, involving public and private enterprises and community participation hold the key to arrest the soaring levels of indoor air pollution due to biomass fuel use and to make a difference to the lives of billons of people.

\section{References}

[1] WHO, "Household air pollution and health. Fact sheet No.292," 2014.

[2] G. Legros, N. HavetCalace, IBrucNardi, B. BoPetrnio, and P. N. D. Programme, "The energy access situation in developing countries: a review focusing on the least developed countries and Sub-Saharan Africa," 2009.

[3] D. Fullerton, N. Bruce, and S. Gordon, "Indoor air pollution from biomass fuel smoke is a major health concern in the developing world," Trans. R. Soc. Trop. Med. Hyg., vol. 102, no. 9, pp. 843-851, 2008.

[4] WHO, "Indoor air pollution: national burden of disease estimates," 2007.

[5] S. Lim et al., "A comparative risk assessment of burden of disease and injury attributable to 67 risk factors and risk factor clusters in 21 regions, 1990-2010: a systematic analysis for the Global Burden of Disease Study 2010,” Lancet, vol. 380, no. 9859, pp. 2224-2260, 2012.

[6] R. Bahadur, P. Praveen, Y. Xu, and V. Ramanathan, "Solar absorption by elemental and brown carbon determined from spectral observations," Proc. Natl. Acad. Sci. U.S.A., vol. 109, no. 43, pp. 17366-17371, 2012.

[7] Ministry of Finance, Government of Pakistan, Pakistan Economic Survey.(2012 -2013). http: //finance.gov.pk/survey_1213.html. 
[8] Pakistan Bureau of Statistics, Pakistan social and living standards measurement survey (Pslm) 2012-13. 2014.

[9] World Bank, Pakistan Strategic Country Environmental Assessment. Report No. 36946pk. 2006. http://siteresources.worldbank.org/SOUTHASIAEXT/Resources/ Publications/448813-1188777211460/pakceavolume1.pdf.

[10] I. Colbeck, Z. Nasir, and Z. Ali, "The state of indoor air quality in Pakistan a review," Environ. Sci. Pollut. Res., vol. 17, no. 6, pp. 1187-1196, 2010.

[11] K. Siddiqui, AR amd Lee, D. Bennett, X. Yang, K. Brown, Z. Bhutta, and E. Gold, "Indoor carbon monoxide and PM2.5 concentrations by cooking fuels in Pakistan," Indoor Air, vol. 19, no. 1, pp. 75-82, 2009.

[12] I. Colbeck, Z. A. Nasir, S. Hasnain, and S. Sultan, "Indoor air quality at rural and urban sites in Pakistan," Water, Air, \& Soil Pollution: Focus, vol. 8, no. 1, pp. 61-69, 2008.

[13] I. Colbeck, Z. A. Nasir, and Z. Ali, "Characteristics of indoor/outdoor particulate pollution in urban and rural residential environment of Pakistan," Indoor Air, vol. 20, no. 1, pp. 40-51, 2010.

[14] I. Colbeck, Z. A. Nasir, Z. Ali, and S. Ahmad, "Nitrogen dioxide and household fuel use in the Pakistan," Science of the total environment, vol. 409, no. 2, pp. 357-363, 2010.

[15] WHO, "Indoor Air Pollution, Household Energy and the Millennium Development Goals, Indoor Air Thematic Briefing 1," 2004.

[16] S. Mehta and C. Shahpa, "The health benefits of interventions to reduce indoor air pollution from solid fuel use: a cost-effectiveness analysis," Energy Sustain. Dev., vol. 8, no. 3, pp. 53-59, 2004.

[17] S. Dasgupta, M. Huq, M. Khaliquzzaman, K. Pandey, and D. Wheeler, "Who suffers from indoor air pollution? Evidence from Bangladesh," Health Policy Plan, vol. 21, no. 6, pp. 444-458, 2006.

[18] S. Dasgupta, M. Huq, M. Khaliquzzaman, K. Pandey, and D. Wheeler, "Indoor air quality for poor families: new evidence from Bangladesh," Indoor Air, vol. 16, no. 6, pp. 426-444, 2006.

[19] T. Urmee and S. Gyamfi, "A review of improved Cookstove technologies and programs," Renewable and Sustainable Energy Reviews, vol. 33, pp. 625-635, 2014.

[20] E. Duflo, M. Greenstone, and R. Hanna, "Indoor air pollution, health and economic well-being," Surv. Perspect. Integr. Envir. Soc., vol. 1, pp. 1-9, 2008.

[21] V. Kishore and P. Ramana, "Improved cookstoves in rural India: how improved are they? A critique of the perceived benefits from the National Programme on Improved Chulhas (NPIC)," Energy, vol. 27, no. 1, pp. 47-63, 2002.

[22] B. Sinha, "The Indian stove programme: an insiders viewthe role of society, politics, economics and education," Boiling Point, vol. 48, pp. 23-26, 2002.

[23] J. Sinton, K. Smith, J. Peabody, L. Yaping, Z. Xiliang, R. Edwards, and G. Quan, “An assessment of programs to promote improved household stoves in China," Energy Sustain. Dev., vol. 8, no. 3, pp. 33-52, 2004.

[24] G. Sarhandi, "High altitude space heating and cooking stoves in Pakistan," Boiling Point, vol. 38, 1997.

[25] M. Saleem, "Status of improved stoves in the northern areas of Pakistan," Boiling Point, vol. 38, 1997.

[26] T. Ahmad and S. Nazir, "Heating-cum-cooking stoves of the FECT project, Peshwar, Pakistan," Boiling Point, vol. 38, 1997.

[27] W. Khushk, Z. Fatmi, F. White, and M. Kadir, "Health and social impacts of improved stoves on rural women: a pilot intervention in Sindh, Pakistan," Indoor Air, vol. 15, no. 5, pp. 311-316, 2005.

[28] A. W. Bhutto, A. A. Bazmi, and G. Zahedi, "Greener energy: Issues and challenges for Pakistan Biomass energy prospective," Renewable and Sustainable Energy Reviews, vol. 15, no. 6, pp. 3207 3219, 2011. 
[29] WHO, "Evaluating household energy and health interventions: A catalogue of methods," World Health Organization, 2008.

[30] M. Edelstein, E. Pitchforth, G. Asres, M. Silverman, and N. Kulkarni, "Awareness of health effects of cooking smoke among women in the Gondar Region of Ethiopia: a pilot survey," BMC Int Health Human Rights, vol. 8, 2008.

[31] G. Osagbemi, Z. Adebayo, and S. Aderibigbe, "Awareness, attitude and practice towards indoor air pollution (IAP) amongst residents of OkeOyi in Ilorin," The Internet Journal of Epidemiology, vol. 8, no. 2, 2009.

[32] R. Heltberg, "Household fuel and energy use in developing countries: A multicountry study," 2003.

[33] R. Heltberg, "Fuel switching: evidence from eight developing countries," Energy Economics, vol. 26, no. 5, pp. 869-887, 2004.

[34] K. Balakrishnan, S. Sambandam, P. Ramaswamy, S. Mehta, and K. Smith, "Exposure assessment for respirable particulates associated with household fuel use in rural districts of Andhra Pradesh, India," J. Expo. Anal. Environ. Epidemiol, vol. 14, no. 1, pp. S14-S25, 2004. 


\section{About This Journal}

EH is an open access journal published by Scientific Online Publishing. This journal focus on the following scopes (but not limited to):

$>$ Air Pollution, Urban and Built Environment

$>$ Occupational Toxicology

$>$ Environmental Biology

$>$ Environmental Biotechnology and Nanotechnology

$>$ Environmental Chemistry

$>$ Environment Change and Human Activity

$>$ Environmental Engineering

$>$ Environmental Management

$>$ Environmental Microbiology

$>$ Environmental Pollution

$>$ Environmental Sciences

$>$ Environmental Technologies

Welcome to submit your original manuscripts to us. For more information, please visit our website: http://www.scipublish.com/journals/EH/

You can click the bellows to follow us:

$\diamond \quad$ Facebook: https://www.facebook.com/scipublish

$\diamond \quad$ Twitter: https://twitter.com/scionlinepub

$\diamond \quad$ LinkedIn: https://www.linkedin.com/company/scientific-online-publishing-usa

$\diamond \quad$ Google+: https://google.com/+ScipublishSOP

SOP welcomes authors to contribute their research outcomes under the following rules:

$>$ Although glad to publish all original and new research achievements, SOP can't bear any misbehavior: plagiarism, forgery or manipulation of experimental data.

$>$ As an international publisher, SOP highly values different cultures and adopts cautious attitude towards religion, politics, race, war and ethics.

$>\quad$ SOP helps to propagate scientific results but shares no responsibility of any legal risks or harmful effects caused by article along with the authors.

$>$ SOP maintains the strictest peer review, but holds a neutral attitude for all the published articles.

$>$ SOP is an open platform, waiting for senior experts serving on the editorial boards to advance the progress of research together.
$>$ Food Contamination

Free Radical Biology

Geosciences and Environmental Physics

Legal Aspects Related to Environment

Soil Remediation

astewater Treatment and Reuse

Water Pollution and Treatment

Xenobiotics 